\title{
Návrh intepretace konce dějin u Hegela
}

\section{An Outline of the Interpretation of Hegel's End of History}

\section{Tomáš Korda}

\begin{abstract}
Abstrakt
Tato stat' je výrazně ovlivněna pronikavou intepretací Hegelovy Fenomenologie ducha, kterou pod titulem Hegelova fenomenologie světa předložila Tereza Matějčková. Stat' vychází z otázky, co z hlediska časovosti dělá duch, který nahlíží rozum pưsobící v dějinách, když tento rozum nahlíži jakožto věčně pưsobící princip (motor) dějin. Duch nevyhnutelně zaujímá perspektivu konce dějin. Tuto perspektivu ale neinterpretuji jako pokus vystoupit z dějin, popírat jejich časovost či přehlížet právě probíhající přítomné dění. Nebot' právě "nynějšek" má duch poznat tak, že v něm kulminuje věčně působící rozum. Z hlediska konce dějin či věčnosti duch v př́tomném poznává to věčně přítomné (totiž Rozum). K objasnění perspektivy konce dějin ji jednak krátce kontrastuji s Nietzscheho a Kantovým náhledem na konec dějin a jednak ji navrhuji připodobnit k „andělu dějin“, kterého viděl Walter Benjamin na obraze Angelus Novus a který zděšen z přítomného couvá zády k budoucnosti.
\end{abstract}

\section{Kličová slova}

budoucnost - duch - Hegel - konec dějin - Walter Benjamin

\begin{abstract}
This paper is deeply inspired by the penetrating interpretation of Hegel's Phenomenology of Spirit, called Gibt es eine Welt in Hegels Phänomenologie des Geistes?, written by Tereza Matějčková. The paper starts from the question what the Spirit does, from the viewpoint of timeliness, when it comprehends the Reason as at work in the history and as eternally at work in the history. What the Spirit does is that it inevitably assumes the perspective of the end of history. Nevertheless, this perspective is not interpreted as a step out of the history
\end{abstract}

Stat' vychází s podporou GAČR, název projektu: Překonávání dualismu mysli a hmoty v novověkém myšlení. Číslo: 19-07384S. 
that denies the timeliness and overlooks the present state of affairs. For the present time is to be comprehended by the Spirit as the very moment into which the eternally active Reason culminates. From the perspective of the end of history or eternality, the Spirit comprehends what is eternally present in the present time (i. e. Reason). For clarification, I briefly contrast Hegel's perspective with Kant's and Nietzsche's view on the end of history and subsequently I suggest that it bears comparison with Benjamin's famous description of the "angel of history" whose horrified view on the past propels him into the future.

\section{Keywords}

future - Spirit - Hegel - end of history - Walter Benjamin

Die Dilettanten, wenn sie das möglichste getan haben, pflegen zu ihrer Entschuldigung zu sagen, die Arbeit sei noch nicht fertig. Freilich kann sie nie fertig werden, weil sie nie recht angefangen ward.

(Goethe)

Since the past no longer clarifies the future, the mind moves in shadows.

(de Tocqueville)

\section{Hegel - první filosof po konci dějin?}

S Hegelovou filosofií je zvykem si spojovat jistou intelektuální megalomanii. Hegel ohlašuje konec všeho možného, umění, náboženství a filosofie či samotných dějin. Čtenář nabývá dojmu, jestli to všechno myslí autor vskutku vážně. Připomeňme nevídanou vehemenci, s jakou Hegel prohlašuje, že jím vypracovaná „geneze pojmu“ je ,jediným a opravdovým vyvrácením spinozismu“. ${ }^{1}$ Chce Hegel opravdu říci, že nejen doposud, ale ani budoucně žádné alternativní vyvrácení spinozismu nebude možné?

Když v Přednáškách $k$ dějinám filosofie Hegel prezentuje svou filosofii jako výsledek dějin filosofie, ${ }^{2}$ jak má čtenář takovou sebeprezentaci chápat, aby Hegela nadobro neodložil? Jistěže se nabízí vyjít dnešnímu uchu vstříc a nabídnout mu relativizující vysvětlení, že Hegel „výsledkem“ jistě míní výsledek pouze prozatímní, platný nikoli věčně, ale pouze pro jeho dobu. Co je to

1 HEGEL, G. W. F. Wissenschaft der Logik. Zweites Buch..., s. 256.

2 HEGEL, G. W. F. Dějiny filosofie III..., s. 483. 
potom ale za výsledek, musíme se ptát, který by platil jenom pro ted', a nikoli už pro zítřek? Odkud by potom Hegel bral takovou vehemenci?

Obdobná rozmělňující čtení nesdílím, protože podle mne míjí nemilosrdný nárok, který Hegel na svou filosofii klade, totiž opravdu věčně stát se svou filosofií na konci dějin a udělat tečk $u^{3}$ za zdánlivě otevřeným příběhem jménem dějiny filosofie. ${ }^{4}$ Jak se však na paradoxu vzletu Minerviny sovy pokusím ukázat, tato tečka za př́během filosofie nesplývá s tečkou, kterou Hegel udělal $z a$ svým filosofickým dílem. Než aby Hegel svým dílem udělal velkolepou tečku za dějinami filosofie, navrhuji, že tato pomyslná tečka ve skutečnosti Hegelovu filosofickému dílu předcházi a stimuluje Hegela k tomu, aby se zamyslel nad významem dějin filosofie. Obdobně dává tečka za větou čtenáři stimul k zamyšlení se nad významem toho, co právě přečetl, co právě ted' skončilo. Navrhuji číst Hegelovu spekulativni metafyziku jako odpověd' na otázku, jak má a musí filosofie vypadat poté, co byl její vývoj právě završen. Hegela proto čtu jako prvního filosofa po konci dějin filosofie. Z tohoto hlediska rozumím i těžko snesitelné lehkosti, s jakou Hegel opakovaně mluví o filosofii vůbec, ačkoli má bez skrupulí na mysli filosofii svou. Z tohoto hlediska chápu, proč svou filosofii (skromně i neskromně zároveň) označuje za výsledek a proč o ní s takovou vehemencí mluví jako o jediném možném vyvracení filosofie Barucha Spinozy.

\section{Paradox vzletu Minerviny sovy}

Proč Hegel programově staví svou filosofii na konec dějin, má podle Matějčkové svou logiku: „[V]še se totiž ukazuje teprve od svého konce. ${ }^{5}$ Teprve na konci dějin lze říci, co jsou dějiny a o co v nich běží. Řečeno kantovsky představuje konec dějin podmínku možnosti poznání dějin. Hegel však tuto podmínku nechápe transcendentálně, ale dává jí ontologický rozměr. „Teprve ve zralosti skutečnosti se proti reálnu objevuje ideálno,“ teprve

3 Obdobnou funkci, jakou plní tečka na konci věty, která nutí čtenáře obrátit se nazpět k tomu, co právě přečetl, plní podle slovinského badatele Gregora Modera Hegelova filosofie ve vztahu k dosavadním dějinám. MODER, G. Hegel and Spinoza..., s. 13, 14 a 131.

4 Konec dějin a konec dějin filosofie spadají u Hegela v jedno, jelikož dějiny filosofie zachycují to, co se skutečně děje, a proto také zachycují to, co se děje, nejdokonaleji. Tudíž konec dějin filosofie musí implicitně znamenat rovněž konec dějin v tom smyslu, že se budoucně nemůže stát nic skutečného, co by filosofii vedlo k revizi svého vlastního konce.

5 MATĚJČKOVÁ, T. Hegelova fenomenologie světa..., s. 326. 
za soumraku vylétá Minervina sova. ${ }^{6}$ Aby se tedy myšlenka o dějinách mohla vůbec objevit a mohla dějiny jako jeden celek učinit předmětem svého poznání, musí být dějiny v ontologickém ohledu završeny. ${ }^{7}$

S pověstným vzletem Minerviny sovy souvisí potíž, o které si nejsem jist, že by ji hegelovské bádání náležitě zohledňovalo. Tato potíž spočívá jednoduše v otázce, odkud bere sova vědění, že má svůj let zahájit. Odkud ví, že dějiny byly završeny, když právě toto vědění má její „přelet“8 nad dějinami vyprodukovat. Vědění o završení dějin stojí na počátku jako předpoklad jejího vzletu, zároveň však i na jeho konci jako výsledek. Do souvislosti s tím dávám Hegelovo tvrzení, že filosofie nestojí ve vzduchoprázdnu, ale „uzavírá se v kruhu“. ${ }^{9}$

Často se opakující výhrada, že se Hegelova filosofie rozvíjí z předem zajištěných a zabezpečených pozic, ${ }^{10}$ protože opisuje kruh, je právě z tohoto důvodu neoprávněná. Vždyt let Minerviny sovy je veskrze riskantní jenom proto, že opisuje kruh. Tudíž teprve až na konci svého letu může sova s úlevou konstatovat, že celý ten její podnik idealizovat dějiny nebyl zbytečný a její předpoklad o konci dějin se ukázal být oprávněný.

Sova s jistotou dopředu nikdy neví, že právě ted' je ten pravý čas vzlétnout. To př́ípadně zjistí až na konci svého letu, ex post. Svým letem tento svůj let ospravedlňuje a ničím jiným, ničím vnějším. Nevyhnutelně tak čelí následujícímu paradoxu „bud'-anebo“. Bud’ vzlétá „př́liš pozdě“, ${ }^{11}$ až když je vše hotovo, zdá se tedy zbytečně, protože nic nového nezjistí, jen to, co už beztak předpokládá. Anebo se ke své radosti na konci svého letu dozvídá novinu, že dějiny jsou již završeny, pak ale čelí podezření, že to ona svým letem dějiny uzavřela, a vzlétla tedy předčasně. Bud' jak bud', vždy se najde dobrý důvod nevzletět. Bud' protože je příliš pozdě, anebo naopak příliš brzo. Bud' v podstatném ohledu dějiny skončily, a jejich filosofická idealizace proto

6 HEGEL, G. W. F. Základy filosofie práva..., s. 32.

7 Toto jejich završení však žádný apokalyptický zánik světa a jeho dějin neimplikuje a implikovat nemůže, protože pak by se vědění o konci dějin ocitlo v jakémsi vzduchoprázdnu a žádnou oporu v dějinách by nemělo. Čili pokračující trvání dějinného vývoje, jak můžeme předběžně konstatovat, nemůže protiřečit poznání konce dějin.

8 Slovo „přelet“ dávám záměrně do uvozovek, abych vyjádřil rezervovanost $\mathrm{k}$ představě, že jde o cosi nivelizujícího, co lze odbýt jedním rázem. Naopak souhlasím s Matějčkovou, že „Hegel tak nevyzývá čtenáře k přeletům nad pouhým jevovým světem, ale spíše podniká hlubinné vrty, které osvětlují, proč jsou věci, tak jak jsou“. MATĚJČKOVÁ, T. Hegelova fenomenologie světa..., s. 31.

9 HEGEL, G. W. F. Základy filosofie práva..., s. 37.

10 Např. HEIDEGGER, M. Hegel..., s. 24.

11 HEGEL, G. W. F., Základy filosofie práva..., s. 32. 
představuje jakousi pomyslnou třešničkou na dortu, která na panujícím stavu věcí nic nemění, takže takovou filosofii si může každý oprávněně odpustit. Anebo - druhá možnost - dějiny neskončily a jsou přinejmenším ve stejně podstatném ohledu před námi jako za námi, a tudíž každá filosofická idealizace završující dosavadní dějiny musí být předčasná a nebere žádný ohled na budoucí vývoj. V jednom i druhém př́ípadě je Hegelova filosofie dějin nařčena z nezájmu o přítomné dění. Protože prý Hegel řeší vývoj následující po „jeho“ konci dějin neuspokojivě, ukazuje se jeho koncepce dějin uskutečněných a završených ve vnitrosvětsky chápaném konci dějin neudržitelnou. Alespoň tak před nedávnem uzavřela svou stat’ Olga Navrátilová. ${ }^{12}$

\section{Apologetika dneška? Ale kdepak}

Ačkoli se Hegel jakýchkoli odkazů k budoucnosti programově vystř́hává a omezuje se na výroky typu, že Amerika je země budoucnosti, ${ }^{13}$ nerovná se jeho teze o konci dějin ztrátě zájmu o dějiny, tedy ani ztrátě zájmu o každý „nynějšek“, který nastane po konci dějin.

Filosofie se nezabývá tím, co bylo, ani tím, co bude, ale tím, co je a je věčně - rozumem - a s tím si vystačíme. ${ }^{14}$

Hegelova filosofie neodhaluje jednoduše rozum v dějinách, nýbrž v dějinách působící rozum odhaluje jako působící věčně, tedy nejen doposud, ale i budoucně. Hegel si proto svou idealizací dosavadních dějin nárokuje současně idealizovat i veškerý budoucí dějinný vývoj. Tvrdí, že rozum v dějinách působit nepřestane. Kdyby tohle netvrdil, nemohl by stavět svou filosofii na konec dějin. Tudíž jeho nezájem o budoucí vývoj je pouze zdánlivý. To, o co v budoucnu ve filosofii poběží, bude spočívat v idealizaci uplynulého kusu dějinného materiálu, v opakování Hegela, které ukáže, že rozum v dějinách působit nepřestal. Fakt, že se filosofie po Hegelovi se záměrem opakovat Hegela neztotožňuje, na věci nic nemění, protože nebyla vyloučena možnost, že filosofie svým odklonem od Hegela (at už má podobu jakoukoli)

12 NAVRÁTILOVÁ, O. Rozum a dějiny u Rousseaua, Kanta a Hegela..., s. 561-562.

13 HEGEL, G. W. F. Filosofie dějin..., s. 63.

14 Tamtéž, s. 63. 
opisuje kruh, na jehož konci na ni Hegel čeká, jak upozorňuje Foucault. ${ }^{15}$ Tento postřeh má o to větší cenu, o co méně lze jeho autora podezřívat z velkých sympatií k Hegelovi.

Máli v idealizaci dějin spočívat Hegelův zájem o přítomnost, tedy i o nynější dění jako i každé budoucí, je potřeba vyvrátit přesvědčení, že poznání rozumu v dějinách představuje onu nakonec zbytečnou třešničku na dortu dějin. A protože dějiny vyústují do právě panující skutečnosti a podle představy konce dějiny se v ní završují, je třeba vyvrátit přesvědčení, že Hegel chce této panující přítomnosti jen slepě či přímo reakčně přitakat. Hegel je dalek toho, aby přítomnosti lacině poklonkoval. Rozum má být totiž v př́itomném světě poznán jako růže na křiži přítomnosti, ${ }^{16}$ tedy jako růže na kříži této právě panujici přítomnosti, do níž dějiny ústí. V souladu s intepretací Fenomenologie ducha od Terezy Matějčkové nepokládám poznání rozumu ve světě a s tímto poznáním spjatou tezi o konci dějin za plochou apologetiku dneška, nýbrž za schopnost obětovat dnešek pro zítřek. ${ }^{17}$

Obětování dneška pro zítřek však v žádném případě neznamená zapomenutí na dnešek či snad jeho potlačení ve prospěch soustředěnosti se na zítřek. Takové soustředění by dnešek naopak prodlužovalo do zítřka, na místo toho, aby se s ním rozloučilo. $\mathrm{S}$ osvícenstvím spjaté investování psychické energie do budoucnosti by navíc šlo proti obecným principům Hegelovy filosofie. Oproti Navrátilové bych proto Hegelovi vůbec nevytýkal optimismus, natož pak prŕilišný. ${ }^{18} \mathrm{Z}$ optimismu lze podezřívat snad jen víru v rozum, se kterou máme podle Hegela ke studiu dějin přistupovat. ${ }^{19}$ Bez této víry by se totiž Minervina sova nejspíše vzlétnout vůbec neodvážila. Na druhou stranu však poznáním rozumu v dějinách tuto svou počáteční optimistickou víru v rozumnost dějin ospravedlňuje a v tomto smyslu i překonává: víru překonává vědění. ${ }^{20}$

15 FOUCAULT, M. Řád diskurzu..., s. 34-35.

16 HEGEL, G. W. F. Základy filosofie práva..., s. 31.

17 MATĚJČKOVÁ, T. Hegelova fenomenologie světa..., s. 335.

18 NAVRÁtillovÁ, O. Rozum a dějiny u Rousseaua, Kanta a Hegela..., s. 562.

19 HEGEL, G. W. F. Filosofie dějin..., s. 14.

20 Co se otázky dějinného optimismu u Hegela týče, souhlasím s Karin de Boerovou, že Hegel svůj optimismus zaměřuje do minulosti, tudíž do budoucna Hegel nic negarantuje. (BOER, K. Hegel. Sway of the Negative..., s. 202.) 


\section{Duch se soustředí na to, co je, a s tím si také vystačí}

V souladu s principy Hegelovy filosofie si proto obětování dneška pro zítřek musíme představovat přesně opačně. Obětovaná prrítomnost není lhostejně či ledabyle hozena za záda, nýbrž spíše se vší náročností před sebe: je zpředmětněna a učiněna předmětem poznání. Jen tak je docíleno náležité pozornosti vưči přítomnému, se kterou Hegel spojuje zkušenost vědomí. ${ }^{21}$ Odvrat od budoucnosti není totiž zdaleka tak snadný, jak se na první pohled může zdát. K soustředění se na přítomnost totiž zdaleka nestačí jen racionálně podniknutý obrat vědomí $\mathrm{k}$ tomu, co je, jako by běželo jen o pomyslné pootočení hlavou. Vždyt na budoucnost se ještě podvědomě soustředí naše tužby, naděje a očekávání nebo naopak strach z toho, co teprve přijde. ${ }^{22} \mathrm{Je}$ těžké od budoucnosti nic neočekávat či z ní nemít strach. Je náročné, aby budoucnost nebyla tématem. Komplementárně tomu pokládám za stejně obtížné zbavit se (podvědomé) nostalgie po minulosti.

S koncem Fenomenologie ducha Hegel stále častěji hovoří o soustředění [Insichgehens] vědomí do sebe, ${ }^{23}$ spolu s tím však zdůrazňuje, že se má vědomí sebe zbavit, že se má vyznat, vyprázdnit se, obětovat se, přiznat se k vlastní vině. ${ }^{24}$ Obojí spolu souvisí. Protože jen když se vědomí sebekriticky samo sebe zbaví, ruku v ruce s tímto vyznáním se bude vskutku soustředit na to, co právě je, co má před sebou, nebot to, co právě je, není pak nic než to, čím zároveň je. To, co je a má před sebou, je jeho vlastní nitro, kterého se zbavilo. Jen když si vědomí vlastní nitro zpředmětní, či spíše si ho nechá světem zpředmětnit, bude konsternováno tím, co je, jakožto tím, čím zároveň je. Na jiné se bude soustředit jako na sebe. Na přítomné bude pohlížet (doslova) jako vlastnímu nitru do tváře, bez jakéhokoli „jako by“. Tím vědomí učiní vlastní nitro duší přítomného světa, ve kterém žije. ${ }^{25}$

Soustředěné vědomí $s e$ tedy učí v přítomném světě poznávat. Učí se důvěřovat světu, či spíše obnovovat svou ztracenou důvěru ve svět. Učí se, že svět svými dějinami nezmařil jeho niterné tužby, přání a očekávání. Vědomí

21 HEGEL, G. W. F. Fenomenologie ducha..., s. 56.

22 Hegelovské řešení, jak se zbavit strachu z toho, co budoucnost přinese, nabízí Walter Benjamin: „Pojem pokroku je nutno založit v ideji katastrofy. Katastrofou je, že to tak ,jde dál‘. Katastrofa není to, co se právě blíží, nýbrž to, co zrovna nastalo." BENJAMIN, W. N [Teorie poznáni a pokroku]..., s. 141.

23 HEGEL, G. W. F. Fenomenologie ducha..., např́íklad s. 472, 485, 487.

24 Tamtéž, s. 481, 487.

25 Srov. HEGEL, G. W. F. Malá logika..., s. 73. 
se naopak učí vidět svět tak, že jeho niterná očekávání a přesvědčení uskutečnil, že ho svět nepodvedl. Ač svět splnil očekávání bezpochyby jinak, než jak si vědomí původně přálo, přesto - přes tuto negaci - se má vědomí k těmto zmařeným, leč uskutečněným úmyslům přihlásit jako ke svým, a tím tuto negaci znovu negovat. Má přestat obviňovat vezdejší svět, podezírat ho a vymlouvat se dokolečka na to, jak ono to myslelo všechno dobře, ale svět mu to zkazil. Na místo toho se vědomí má postavit světu čelem, vyznat se, že tyhlety všechny zpackané činy - tvořící celý svět a jeho dějiny - jsou pravdou jeho ryzích úmyslů. Tudíž jeho úmysly nebyly tak ryzí, jak si vědomí původně myslelo. V tomto smyslu se má učit z dějin světa. Má si nechat poskvrnit si „nádheru svého nitra“.${ }^{26}$ Když vědomí vidí, že jeho představy jsou již hotové, když neguje negaci, kterou je svět, tak pohlíźí konsternovaně světu do tváře jako do svého právě zpředmětněného nitra, jako do zrcadla. ${ }^{27}$ Pozorností vưči přítomnému coby vlastnímu nitru se vědomí osvobozuje od potřeby investovat nostalgicky své nitro do minula, nebo naopak optimisticky do budoucna. Pak si vědomí vystačí s tím, co je a je věčně, protože věčně bude platit, že se má učit ve světě poznávat své vlastní nitro, a odhalovat tak rozumnost světa.

V kontextu soustředění se na přítomné potom čtu často citovaný pasus z předmluvy k Fenomenologii ducha, ve které Hegel popisuje, v čemže to spočívá život ducha. Duch se zaprvé neleká (nostalgicky) smrti a není ani se vším bohorovně hned hotov v očekávání toho, co přinese zítřek, aby s tím byl zase hned hotov. Nýbrž duch pohlíží smrti do tváře a navíc tento pohled do tváře negativity dokáže unést a prodlévat u ní, což vyžaduje té nevyšší síly. ${ }^{28}$ Život ducha nemá úzkost před vezdejším světem, neštítí se ho a nestěžuje si, jak usmrcuje jeho ryzí niterné úmysly, nýbrž tomuto procesu usmrcování pohlíží do tváře, vhazuje do něho své velectěné nitro, a tím si ho nechává zpředmětnit, aby mu svět následně ukázal, čím je. Duch se nebojí učinit se věcí (sich selbst zum Ding machen), když bychom využili provokativního výrazu, který Hegel častěji než ve Fenomenologii užívá ve své jenské „filosofii ducha“ z let 1805/6. ${ }^{29}$

26 HEGEL, G. W. F. Fenomenologie ducha..., s. 407.

27 Jako prríklad uvedu knihu Ecology without Nature, ve které Timothy Morton ukazuje, že to, co si pod přírodou nakonec představujeme, je ideologická projekce, kterou si současný duch (lidstvo) vymyslelo, aby mu prŕroda jako základ světa garantovala jednotu tohoto světa. Od této ideologické projekce jménem příroda se musíme podle Mortona osvobodit, abychom otevřeli prostor skutečně ekologickému stanovisku ke světu a osvobodili svět od prrírody.

28 HEGEL, G. W. F. Fenomenologie ducha..., s. 69.

29 K tomu: QUADFLIEG, D. Der Geist der Sache..., s. 94. 
Protože duch ve zdejším světě poznává, jak svět jeho niterné záměry již uskutečnil, je ve světě doma. Svět je v tomto ohledu pro ducha rozumný. Duch se obejde bez toho, co bylo a bude, a vystačí si s tím, co je, protože to, co je a je věčně, není pro něho „nějaký“ ten (metafyzický) rozum ve světě a dějinách, nýbrž rozum odkázaný na jeho schopnost ho ve světě poznávat, a tím činit svět rozumným. Duch propouští své nitro ze sebe na svobodu $\mathrm{v}$ dobré viŕre $\mathrm{v}$ rozumnost tohoto světa. Retrospektivním rozpoznáním svého nitra ve světě tuto svou víru překonává a stvrzuje. Svět je rozumný, nakolik je světem ducha a nakolik v něm duch dokáže být u sebe. ${ }^{30}$ Nanejvýš zajímavé jsou potom pro Hegela období, kdy se duch „rozešel se světem svého jsoucna“. ${ }^{31}$ Jenom o takovém světě, se kterým se duch rozešel, by snad šlo říci, že je objektivně nerozumný. Takový svět je však zákonitě cítit revolucí.

\section{Kant, Nietzsche a Navrátilová}

Pro záměr této statě je však zásadní položit si otázku, co „dělá“ duch z hlediska časovosti, jestliže se ve světě poznává, jestliže si jím nechává zpředmětnit své nitro, a tím odnímá světu jeho cizost a danost. Zpředmětnění si sebe obnáší distanci k sobě samému, tedy ústup před sebou samým. Kam však z hlediska časovosti duch ustupuje, když ustupuje před sebou jakožto před přítomným světem, který najednou zrcadlí jeho dávné niterné sny, úmysly, konstrukce či představy? Duch - tvrdím - nemůže jinam než ustupovat vzad do budoucnosti.

Čím více je duch daného společenství schopen „nacouvat“ do budoucnosti a ze vzdálenější budoucnosti nahlížet přítomný svět, tím více je ve světě doma, tím více je dané společenství duchaprítomné a tím větší objem budoucnosti očekává, že má před sebou. Což vypovídá o stavu, úrovni a obecně vzdělání ducha tohoto společenství. Čím abstraktnější jsou jeho představy o budoucnosti a čím méně je schopen se rozvrhnout do budoucnosti, tím je dané společenství nevzdělanější a slabší.

V mé interpretaci potom duch daného společenství sílí spolu s tím, čím více dokáže být ve světě doma a v dějinách vidět účinkování či působení

30 Provázanost objektivní rozumnosti světa s duchem, který tuto rozumnost nahlíží, zaznívá v Hegelově větě, že „duch je pouze pro ducha“ (HEGEL, G. W. F. Vorlesungen über die Philosophie der Religion II..., s. 189), nebo rovněž v jeho nástupnické řeči na berlínské univerzitě, že svět se jeví rozumný jen pro člověka, který ho rozumně nahlíží (HEGEL, G. W. F. Enzyklopädie der Wissenschaft III, Anhang..., s. 406.).

31 HEGEL, G. W. F. Fenomenologie ducha..., s. 57. 
svého nitra, svých představ, předsudků a konstrukcí, které nyní v jeho očích zakládaji to, co předtím redukoval jen na důsledek vnějších vlivů, na danost světa či na objektivní zákonitosti světových dějin. Duch, jenž ví, že svým sebepoznáním se v dějinách v nich také působí, potom stojí na konci těchto dějin. Od sebe jakožto rozumného nitra přítomnosti se vymezuje, sám sobě se zcizuje a ustupuje směrem do budoucna až na samý konec dějin, protože až sem musí duch ustoupit, protože až v této „absolutní rozervanosti“32 vidí to, co je, jako to, co je zároveň věčné. Duch tak proráží až do té nejzazší možné budoucnosti, a tím smiřuje ten největší možný protiklad, kterým je on sám: napětí mezi přítomností a věčností.

$\mathrm{V}$ tomto bodě mého výkladu si proto dovolím polemizovat s tvrzením, že se „Hegel pokouší o takovou syntézu mezi věčností a časovostí, která se na problému konce dějin ukazuje jako neudržitelná“, protože Hegel prý zbavuje dějiny „napětí mezi imanencí a transcendencí“. ${ }^{33}$ Toto tvrzení nechápu a předložený argument mi k tomu nijak nepomáhá, protože konec dějin, jak ho čtu, je jménem pro tu nejkrajnější rozervanost, které je duch schopen a ve které si je duch schopen to nejvyšší napětí mezi imanencí a transcendencí zniternit. To duch je napětí mezi časovostí a věčností, přítomností a koncem dějin.

Než se k tomu vrátíme, přibližme si Hegelovo pojetí konce dějin tím, že ho vymezíme vůči Kantovi a Nietzschemu. Bud' konec (a začátek) dějin „k dějinám ve vlastním smyslu nepatř̌i “34 a představuje úběžník, ke kterému se dějiny sice donekonečna přibližují, ale nikdy ho nedosáhnou (Kant), anebo nic jako konec dějin neexistuje a nemá smysl o něm ani uvažovat, protože „kdyby svět měl cíl, musel by již být dosažen“35 (Nietzsche ${ }^{36}$ ), anebo za třetí, konce dějin jakožto poznání toho, co je a je věčně, bylo již dosaženo (Hegel).

Pozoruhodné je, že Hegelovo stanovisko naráz syntetizuje obě předchozí a zároveň je překonává, přestože (nebo spíše protože) jim dává částečně

32 HEGEL, G. W. F. Fenomenologie ducha..., s. 69.

33 NAVRÁtilovÁ, O. Rozum a dějiny u Rousseaua, Kanta a Hegela..., s. 562.

34 Tamtéž, s. 560.

35 NIETZSCHE, F. Nachgelassene Fragmente 1884-1885..., s. 556; KSA: 11.36 [15].

36 Záměrně dávám Nietzscheho a Kanta do závorky, protože jejich koncepci dějin se zde nemohu věnovat natolik důkladně, abych mohl závorky odstranit. Závorky tedy říkají, že si za jednu koncepci dějin můžeme zhruba dosadit Kanta a za druhou Nietzscheho. Vůbec není mým záměrem ukazovat, že Nietzsche či Kant zastávali tu a tu koncepci dějin. Spíše mi jde o tyto dvě koncepce samotné bez ohledu na to, kdo je zastával, či zda vůbec někdo je zastával. 
za pravdu. Kant má pravdu, že konec dějin existuje, nikoli však jako nepoznatelný úběžník dějin. Rovněž i Nietzsche má pravdu v tom, že dějiny žádný konec nemají, avšak nemají ho pouze v Kantově smyslu (nepoznatelné) transcendentální ideje. Hegel pak vyvrací (Kantovu) představu konce dějin ve smyslu nedosažitelného zásvětního „udavače“ jejich směru tím, že dává částečně za pravdu (Nietzscheho) představě, že dějiny trvají už dostatečně dlouho na to, aby svého cíle dosáhly. $\mathrm{Z}$ toho však Hegel nevyvozuje závěr, že dějiny tudíž žádný cíl nemají. Hegel naopak svou filosofií ukazuje, či se přinejmenším její pomocí ukázat snaží, že dějiny svého cíle již dosáhly a rozum působící v dějinách se poznal jako to, co je a skutečně věčně je. Odtud lze vyvodit argument, proč si Hegel nepředstavuje poznání konce dějin ve smyslu dohlédnutí až na konec dějin. Kromě toho, že se takového vyhlížení do budoucna programově zř́kal, ${ }^{37}$ je důležité si uvědomit, že kdyby si Hegel nebyl schopen pod poznáním konce dějin představit nic jiného než toto jakési jasnožrivé vidění až na samý horizont vší budoucnosti, potom by mu nezbývalo než dát za pravdu bud' Kantovi, že takový konec je nepoznatelný, anebo Nietzschemu, že prostě žádný takový cíl dějin neexistuje.

Aby Hegel nemusel přistoupit na stanovisko ani jednoho z obou myslitelů, musel si konec dějin představovat tak, že je nejen poznatelný, ale zároveň neodlučitelný od duchovního výkonu, kterým je konec dějin poznán. Ohledně této neodlučitelnosti připomeňme, že pro Hegela je rozum jenom jeden ${ }^{38}$ a poznání rozumu musí být chápáno zároveň jako vlastní sebepoznání, jako čin tohoto rozumu, či přesněji ducha. Absolutno či v našem kontextu konec dějin si nemáme představovat tak - jak Hegel zdůrazňuje v úvodu k Fenomenologii ducha -, že stojí na jedné straně barikády a na její protilehlé straně stojí poznání absolutna. ${ }^{39} \mathrm{~V}$ opačném př́ípadě hrozí či je přímo zaručeno metafyzické zvěcnění rozumu či absolutna. Proto navrhuji, že konec dějin nesmí být pokládán výlučně za předmět, který má být poznán, ale ve stejné míre („ebensosehr“) má být chápán také jako perspektiva, duchovní výkon poznávající konec dějin. Co se děje s tímto výkonem z hlediska časovosti, považuji přinejmenším za podstatné jako předmět (tj. rozum), který poznává.

37 Srov. HEGEL, G. W. F. Filosofie dějin..., s. 283-284.

38 HEGEL, G. W. F. Úvod. O podstatě..., s. 299.

39 HEGEL, G. W. F. Fenomenologie ducha..., s. 95. 


\section{Hegelův duch alias Benjaminův „anděl dějin“}

Navrhuji představit si ducha tak, že šponuje ono zmíněné napětí mezi přítomností a věčností, protože je fascinován tím, co vidí. Fascinující musí být pohled $n a$ to, čím dějiny končí, čím vrcholí. Tento pohled žene ducha nezadržitelně zády do budoucnosti až samý na konec dějin, kde zaujímá perspektivu konce dějin. Přirozeně jen odtud lze vůbec nahlížet to, co je, jako to, co je a je věčně. Má-li být jsoucí nahlédnuto jakožto věčně jsoucí, pak jedině z perspektivy konce dějin. Ono těžko pochopitelné „couvání“ do budoucnosti nemůže nepřipomenout „anděla dějin“, kterého viděl Walter Benjamin na obraze Angelus Novus od Paula Kleeho.

[Anděl dějin] jako by hodlal opustit něco, čím je fascinován. Oči má vypoulené, ústa dokořán a jeho kř́́dla jsou rozpjatá. [...] Tváří se obrací do minulosti. Co se nám jeví jako řetěz událostí, to vidí jako jednu jedinou katastrofu, která bez přestání kupí trosky na trosky a hází mu je pod nohy. Rád by prodlel, rád by vzbudil mrtvé a spravil, co je rozbité. Ale z ráje věje vichřice, která se opírá do jeho křídel a má takovou sílu, že je anděl už nemůže složit. Tato vichřice ho nezadržitelně pohání do budoucnosti, jíž nastavuje záda, zatímco hora trosek před ním roste do nebe. Tato vichřice je tím, čemu ř́íáme pokrok. ${ }^{40}$

V mé intepretaci vypadá jako anděl dějin i duch, který zaujme perspektivu konce dějin. I duch má ústa dokořán, křídla rozpjatá a údiv ve tváři. Byt s tím rozdílem, že není fascinován přesně tím, čím anděl dějin, který za nezáživným řetězem událostí vidí jednu velkou katastrofu, jež mu hází trosky pod nohy. Ducha spíše fascinuje sama vichřice, která ho vlastně zachraňuje před troskami, jež se mu kupí pod nohami. Tou vichřicí je rovněž pro Hegela pokrok, avšak ten se neděje slepě automaticky, nýbrž v dějinách působí jen v té míře, v jaké je duch schopen v dějinách - v těchto troskách a jatkách poznat rozum. Jen pak se duchu opírá rozum do kř́ídel a nezadržitelně ho žene do budoucnosti až na samý konec dějin. Žene ho tam jen proto, že ho v dějinách (tady a ted', v prostoru a čase) poznává a současně ho poznává tak, že tento rozum v dějinách působí věčně. Proto jen z hlediska konce dějin nemůže působící rozum představovat nic metafyzického. Na druhou stranu zvnějšku se vše jeví jinak: Jestliže duch na toto své účinkování v dějinách re-

40 BENJAMIN, W. O pojmu dějin..., s. 12. 
flektuje a je touto reflexí donucen „dělat“ spekulativní metafyziku a mluvit např́klad o konci dějin, lze ho lehce z metafyzičnosti nařknout.

\section{Jak duch rozráží kontinuum homogenního času}

S Benjaminovým pojetím dějin má perspektiva konce dějin ještě jiný styčný bod. V XV. tezi $O$ pojmu dějin mluví Benjamin o „vědomí, že je třeba rozrazit kontinuitu dějin“. Toto vědomí je charakteristické pro revoluční třídy v okamžiku jejich akce a prakticky se vyznačuje například potřebou zavést nový kalendář. Tento den, jímž kalendář začíná, je pamatován a vrací se v podobě svátků. ${ }^{41}$ Nadto činí perspektiva konce dějin svátečním a jedinečným každý jednotlivý den, každý den jako by stál za zavedení nového kalendáře a čas jako by začínal běžet nanovo. V jejích očích se totiž rozum zjevuje každým všedním dnem. Každý den je svátečním a dotýká se věčnosti. Jako by byl revolučním a na věčnost pravdivým, podobně jako křestanství nebo Velká francouzská revoluce. Zesvátečnění všední každodennosti rozráží kontinuitu dějin a udržuje ji rozraženou. Perspektiva konce dějin totiž mezi sebe a nynější sváteční den klade veškerou budoucnost, která teprve bude, avšak pouze $\mathrm{z}$ hlediska časovosti, kdežto z jejího hlediska jako by vůbec nebyla tématem a byla průhlednou. Řečeno s Hegelem, budoucnost vyplňuje průhledný rozdíl, který žádným rozdílem není. Tímto rozdílem Hegel definuje sebevědomí, resp. ducha. Pokud duch prohlíží na přítomný den skrze veškerou budoucnost, nahlíží tento den očima věčnosti - konce dějin. Čím vzdělanější je, tím věčnější je to, co v proudu dění poznává, tím větším objemem budoucnosti pohlíží na př́ítomný den. Čím je vzdělanější, tím výrazněji produchovňuje nynějšek věčností. Z banální všednosti obyčejného „nyní“ činí uzel dějin. ${ }^{42}$

Protože však každé sebevědomí produchovňuje přítomné „nyní“ v míře objemu budoucnosti, kterou mezi sebe a přítomný den vměstnává, nahlíží na „nynějšek“ z téže strany jako perspektiva konce dějin, ,jakoby“ z budoucnosti. Rozdíl mezi ní (Hegelem) a obyčejným sebevědomím pak spočívá ,jen“ v objemu budoucnosti, kterým je dotyčné sebevědomí schopno prohlédnout. Čím výrazněji žije člověk takříkajíc ze dne na den, tím méně je schopen každý tento den produchovňovat, vážit si ho. V perspektivě

42 HEGEL, G. W. F. Filosofie dějin..., s. 283-284. 
Waltera Benjamina je pro něho čas tím homogennější a prázdnější, čím méně je naplněný nynějškem, ${ }^{43}$ neboli čím méně se nynějšek vylévá do času směřujícího $\mathrm{k}$ věčnosti.

\section{Kontrast smyslové jistoty a absolutního vědění}

Nikoli náhodou je u Hegela ta nejméně vzdělaná podoba vědomí tou, která je nejvýrazněji zmítaná časem. Hegel ji nazývá smyslovou jistotou. Pro tuto první podobu vědomí Fenomenologie ducha je pravdou právě vnímaná bezprostředně smyslová danost, tudíž s každou časoprostorovou změnou se smyslové jistotě rozplývá to, co právě pokládala za pravdu. Každou vteřinou zažívá smyslová jistota jakýsi existenciální šok. Pravda, tato jednoduchá bezprostřednost, jež právě vyvanula, byla celá jeji pravda, která tu byla jenom pro ni a kterou jenom ona pokládala za pravdu. ${ }^{44}$ Smyslová jistota proto žije nesnesitelný život z vteřiny na vteřinu.

Nesnesitelnost jejího života pak ostře kontrastuje s nejdokonalejší či nejvzdělanější podobou vědomí, s absolutním věděním, které - píše Hegel - vyhladilo čas. ${ }^{45}$ Poplatně intepretaci Terezy Matějčkové nepovažuji slova o „vyhlazení času“ za doklad Hegelova „ztřeštěného“ idealismu. Hegel zde nemluví o jakémsi „apokalyptickém“ zániku světa s jeho časovostí. ${ }^{46}$ Absolutní vědění se dál zjevuje ve světě, jen čas a vlastní konečnost pro něho nemají význam překážky a omezení. ${ }^{47}$ Každý okamžik pro absolutní vědění trvá věčně. Každá přicházející vteřina stvrzuje, než aby ohrožovala to, co absolutní vědění pokládá za pravdu. Pakliže s budoucím časem přijde něco, nějaký předmět, na kterém vědomí proti své nevoli bude muset učinit zkušenost a vyznat se ze svého omylu, pak to neznamená nic jiného, než že předtím absolutního vědění nedosáhlo.

V tom tkví ten jediný důvod, proč se domnívám, že absolutní vědění nemůže nic překvapit. Protože jakmile absolutní vědění něco překvapí či vykolejí, jakmile s něčím „bojuje“, není již absolutním věděním. Jakmile čelí předmětu, na kterém ke svému „zděšení“ musí učinit novou zkušenost, v ten

43 BENJAMIN, W. O pojmu dějin..., s. 14.

44 HEGEL, G. W. F. Fenomenologie ducha..., s. 105-106.

45 Tamtéž, s. 483.

46 MATĚJČKOVÁ, T. Hegelova fenomenologie světa..., s. 332.

47 Srov. tamtéż, s. 334. 
moment zjištuje, že absolutním věděním ještě nikdy vlastně nebylo. ${ }^{48}$ Jen proto, že ví, že ho nic nepřekvapí, nebojí se přicházející bezprostředností „nechat vychovat opět až k dospělosti“, jak stojí v samotném závěru Fenomenologie ducha.$^{49} \mathrm{~V}$ této ochotě vcházet do světa a ve světě své absolutní vědění osvědčovat a testovat, ${ }^{50}$ nechávat se novým opětovně vzdělat a novou bezprostředností se udržovat na vrcholku přítomnosti, v tom spočívá absolutnost absolutního vědění. Absolutní vědění nepotlačuje bezprostřednost, protože ví, že ji potřebuje, aby mělo z čeho rezultovat, aby mělo co ab-solvovat. Ví, že bezprostřednost čeká přede dveřmi jen proto, aby ho na svých nohách vynesla ${ }^{51}$ Ochota vychovat se právě přicházejícím znamená nepodmaňovat si mocensky zítřek předsudky a pravdami včerejška. Absolutní vědění nepodléhá domnění, že ví úplně „vše“. „Vše“ je právě to, co neví. Ví pouze, že zítřek nepřinese nic, čím by se nemohlo nechat znovu vychovat, co by nemohlo absolvovat. „Nic“ proti zítřku nemá a nic mít proti zítřku ani nemůže, protože vědění, kterým by snad mohlo chtít zítřek „trumfnout“, je právě tím, čeho se na své cestě $\mathrm{k}$ absolutnu muselo vzdát. ${ }^{52}$ Absolutní vědění postrádá vědění, kterým by si mohlo chtít podmanit zítřek. Proto ani po ničem takovém netouží. V tomto smyslu je zbavené touhy. Protože obětovalo své vědění, kterým by mohlo chtít se nad zítřek povyšovat, vychází zítřku vstříc, stojí v noci na prahu zítřka.

Tato až extatická otevřenost budoucímu, tvrdím, je důvodem, proč musí mít Matějčková pravdu, jestliže píše, že Hegel v poslední kapitole nic nového neřekne.

Poslední podoba ducha nemá vlastní předmět. Namísto toho Hegel uvádí své čtenáře do "galerie“ minulých podob vědomí. ${ }^{53}$

48 MATĚJČKOVÁ, T. Hegelova fenomenologie světa..., s. 331.

49 HEGEL, G. W. F. Fenomenologie ducha..., s. 487.

50 MATĚJČKOVÁ, T. Hegelova fenomenologie světa..., s. 38.

51 HEGEL, G. W. F. Fenomenologie ducha..., s. 91.

52 Jestliže ideologií nazveme toto vědění, u kterého pro jeho neabsolutnost hrozí, že bude instrumentálně vyžito k mocenskému či hegemonickému podmanění si světa a všeho toho, co přinese zítřek, potom je nasnadě číst Hegelovu Fenomenologii ducha jako kritiku ideologie avant le lettre.

53 MATĚJČKOVÁ, T. Hegelova fenomenologie světa..., s. 328. 
Absolutní vědění je absolutní proto, že žádný svůj vlastní obsah ani předmět nemá. ${ }^{54}$ Ale ani mít nesmí. Kdyby svůj specifický předmět mělo, nebylo by „pouhou“ rekapitulací předchozích podob vědomí. Vědomí je absolutní, když před sebou již žádný svůj předmět nemá, a tedy neni nič podobou vědomi. Co má před sebou, je pouze vzpominka na to, že má veškerou zkušenost za sebou. A protože tato vzpomínka je vším, co vědomí má, má v ní také vědění toho, čím je, má v ní sebe jakožto rozdíl, který žádným rozdílem není, tj. pojem.

Uzavřené do vzpomínky na učiněnou zkušenost vychází absolutní vědění zítřku vstříc. Nebojí se zítřka. Avšak než aby zítřek až do pomyslného konce dějin stál na straně absolutního vědění, stojí spíše toto vědění na straně zítřka, jím si nechává dávat za pravdu - zaujímá perspektivu konce dějin.

\section{Seznam použitých zdrojů}

BENJAMIN, Walter. $N$ [Teorie poznáni a pokroku]. In BENJAMIN, Walter. Teoretické pasáže. Uspořádal a přeložil M. Ritter. Praha: Oikoymenh 2011.

BENJAMIN, Walter. O pojmu dějin. In BENJAMIN, Walter. Dilo a jeho zdroj. Přeložila V. Saudková. Praha: Odeon 1979.

BOER, Karin de. Hegel. Sway of the Negative. New York: Palgrave Macmillan 2010.

FOUCAULT, Michel. Řád diskurzu. In FOUCAULT, Michel. Diskurz, autor, genealogie. Přeložil P. Horák. Praha: Svoboda 1994.

FULDA, Hans Friedrich. Das Absolute Wissen - Sein Begriff, Erscheinen und Wirklich-Werden. Revue de métaphysique et de morale 2007(3), s. 338-401.

HEGEL, Georg Wilhelm Friedrich. Dějiny filosofie III. Přeložil J. Husák - J. Bednářr. Praha: Academia 1974.

HEGEL, Georg Wilhelm Friedrich. Enzyklopädie der Philosophischen Wissenschaften III (1930). In HEGEL, Georg Wilhelm Friedrich. Werke in 20 Bänden, bd. 10. Vyd. E. Moldenhauser - K. M. Michel. Frankfurt a. M.: Suhrkamp 1986.

HEGEL, Georg Wilhelm Friedrich. Fenomenologie ducha. Přeložil J. Patočka. Praha: ČSAV 1960.

HEGEL, Georg Wilhelm Friedrich. Filosofie dějin. Přeložil M. Váňa. Pelhřimov: Nová tiskárna Pelhřimov 2004.

HEGEL, Georg Wilhelm Friedrich. Malá logika. Přeložil J. Loužil. Praha: Svoboda 1992.

HEGEL, Georg Wilhelm Friedrich. Úvod. O podstatě filosofické kritiky vůbec a o jejím vztahu k současnému stavu filosofie zvláště. Filosofický časopis 2003, 51(2), s. 299-308.

54 Alternativní výklad absolutního vědění navrhuje např. Fulda, H. F. Das Absolute Wissen Sein Begriff, Erscheinen und Wirklich-Werden..., s. 338-401. 
HEGEL, Georg Wilhelm Friedrich. Vorlesungen über die Philosophie der Religion II. In HEGEL, Georg Wilhelm Friedrich. Werke in 20 Bänden, bd. 17. Vyd. E. Moldenhauser - K. M. Michel. Frankfurt a. M.: Suhrkamp 1986.

HEGEL, Georg Wilhelm Friedrich. Wissenschaft der Logik. Zweiter Band. In HEGEL, Georg Wilhelm Friedrich. Werke in 20 Bänden, bd. 6. Vyd. E. Moldenhauser K. M. Michel. Frankfurt a. M.: Suhrkamp 1986.

HEGEL, Georg Wilhelm Friedrich. Základy filosofie práva. Přeložil V. Špalek. Praha: Academia 1992.

HEIDEGGER, Martin. Gesamtausgabe. 68 : Abt. 3, Unveröffentlichte Abhandlungen, Vorträge - Gedachtes, Hegel: 1. Die Negativität. 2. Erläuterung der „Einleitung“ zu Hegels „Phänomenologie des Geistes“ [cit. jako „Hegel“]. Frankfurt am Main: Klostermann 1993.

MATĚJČKOVÁ, Tereza. Hegelova fenomenologie světa. Praha: Oikoymenh 2018.

MODER, Gregor. Hegel and Spinoza. Substance and Negativity. Illinois: Northwestern University Press 2017.

MORTON, Timothy. Ecology without Nature. Cambridge: Harvard University Press 2007.

NAVRÁTILOVÁ, Olga. Rozum a dějiny u Rousseaua, Kanta a Hegela. Filosofický časopis 2017, 65(4), s. 543-562.

NIETZSCHE, Friedrich. Nachgelassene Fragmente 1884-1885. In NIETZSCHE, Friedrich. Sämtliche Werke: kritische Studienausgabe in 15 Bänden. Hrsg. Giorgio Colli und Mazzino Montinari Nietzsche. München: Deutscher Taschenbuch Verlag 1988.

QUADFLIEG, Dirk. Der Geist der Sache. In Hegel-Jahrbuch. Volume 2010, Issue 1, s. 89-94. DOI: https://doi.org/10.1524/hgjb.2010.12.jg.89.

\section{Mgr. Tomáš Korda}

Doktorand FF UK, Ústav politologie, Filozofická fakulta, Univerzita Karlova

U Kř́že 8, 15800 Praha 5 - Jinonice, Česká republika

t.korda@seznam.cz

$+420728455339$ 
